\title{
Improving Students Vocabulary Through Blindfold Games
}

\author{
Tauricha Astiyandha ${ }^{1}$, \\ *Universitas Islam As-Syafi 'iyah, Jl. Jatiwaringin Raya no 12 PondokGede, Jakarta Timur, \\ Indonesia,Email: taurichaa@gmail.com \\ Lisa Muchlisoh ${ }^{2}$, \\ **Universitas Islam As-Syafi 'iyah, Jl. Jatiwaringin Raya no 12 PondokGede, Jakarta Timur, \\ Indonesia, Email: Lisamuchlisoh29@gmail.com
}

\begin{abstract}
:
This study aims to identify the extent to which student knowledge in understanding vocabulary using blindfold games. By using blindfold games, students are expected to understand more in using vocabulary. Blindfold is the method students use about things in class. After teaching vocabulary to students, both writing and pronunciation, to practice descriptions, we can use the blindfold game. Before entering the game, it would be better if students run simple description phrases. Enter the game, students as usual describe them with cloth or sketches that have been prepared. After all students are closed, the teacher will provide ready things like books, pencils and pens. Students are given to describe these objects. Students who successfully describe and guess correctly. This is done to find out how students cope with vocabulary. The research design of the study was classroom action research. In this research, there were four phrases, plan, action, observe, reflection. This research will be conducted by two cycles to analyze data. The research investigated the eight grade students vocabulary of MtsN 31 Jakarta Timur which was started in August 10, 2018 and ended in September 14, 2018. Researchers collect data by teaching them about vocabulary using bliindfold games and documenting. Data comes from test results and lesson plans. Data collection method is observation. this research was conducted at MtsN 31 Jakarta with 34 participants. This study was successful because there was a significant increase in the first cycle with an average of 61 and the second with an average of 70. This study helped students improve vocabulary.
\end{abstract}

\section{Keywords : Vocabulary, Blindfold}

\section{Introduction}

English is one of the International Languages. This is used almost countries in the world to communicate with each other. English is the most important language in the word because English has been used for around 7.53 billion people to communicate with others. English in Indonesia itself, the position of language is a foreign language. The term foreign language in the field of language teaching is different from the second language. Foreign language is a language that is not used as a communication tool in certain countries where language is taught. Whereas the second language is a language that is not the main language but it is one of the languages used in general in a country. Meanwhile, the facts are heard, English implements its power World. Because English is an International Language, so all states are in the world is forced to learn and use it, either as a first or second language language. This aims to improve and develop their country. We can see the fact that almost all countries in the world speak English. 
English is learned and assessed at school there are four aspects:

Speak, Listen, Write and Read. In addition to the four English skills, students must have good English comprehension skills such as vocabulary, to support their four language skills. As one of the components of English, vocabulary is very important to learn. Without mastering vocabulary, that is students will not be able to master four language skills, or study English. (Richard ,2005 P. 5) states that vocabulary is a core component

listening, speaking, reading and writing. Vocabulary is very important to do learned by students who want to master English. When we learn English, we must first understand vocabulary. The most important aspect in English is vocabulary. In learning English, we cannot translate stories, or understand what people say, and if we don't understand vocabulary.

Vocabulary is the total number of words that make up language (Hornby, 2002 P.6) Like (Nunan, 2005, P.121) states that "vocabulary is a collection of words that someone knows ". That is the reason why without sufficient vocabulary, students will experience difficulties in learning language. Vocabulary is the most important aspect of learning English. Because English cannot be understood without vocabulary. Without vocabulary, we cannot study or practice English. How do we can understand English or anything written in English while we don't have anything about vocabulary. How can we learn or practice English, while we know the vocabulary. Can we imagine how we can speak English while we don't have vocabulary and the fact that vocabulary is a very important aspect in learning English, but the most important aspect is in learn English.

Vocabulary as an important aspect of English will make students easy to communicate with each other. (Jack and Willy,2002 P.225). As we have known that at English curriculum in school students must master at least 1500 vocabulary words and to develop student vocabulary. The teacher must teach techniques so that they can receive English easily, but students must develop your own vocabulary too.

In addition to knowing the words and meanings of English, students also need to know how words work together in English sentences. We concluded that teaching vocabulary is not only to give meaning to words but to teach how the word works and has meaning. in this case grammar must be taught together with vocabulary to avoid many problems in learning English. Problems in learning and teaching English are still in school, because English is completely different from Indonesian in structure, pronunciation and vocabulary. and this english club activity we teach the method of how students can understand English vocabulary well and correctly.

Nowdays many students who are less understanding and less able to place vocabulary. The purpose of this study was to identify the extent to which students' knowledge in understanding vocabulary using blindfold games. By using games blindfold students are expected to understand more in using vocabulary. Blindfold is a method that students use about things in class. After teaching vocabulary to students, both writing and pronunciation, to practice descriptions, we can use the blindfold game. Before entering the game, it would be better if students run simple description phrases. Step into the game, students as usual to describe them with cloth or sketches that have been prepared. After all students are closed, the teacher will provide ready things such as books, pencils and pens. Students are given to describe these objects. Students who successfully describe and guess correctly, he will get a prize or prize.

Based on the result this blindfold game is improving students vocab that students will be more caring and have the correct vocabulary placement because this method is made in a fun way. 


\section{Literature Review}

\section{A. Definition of Vocabulary}

Vocabulary cannot be separated from the language, it is important part of language. Hari muki krida laksana point out "vocabulary is a component of a language that maintains all of information about meaning and using word in language" it means that vocabulary is the important of language, without vocabulary the language cannot be used to maintain all information in language. It can be say that vocabulary is smallest unit of speech that processes individual meaning to speak and can be used to interact one other and vocabulary can be say as a group of words on certain language as a part in teachinglearning in a foreign language.

In the past, vocabulary teaching and learning was given a little priority in the English language program, but recently there has been new interest in learning and teaching. (Richards and Renandya, 2002 P. 255). Vocabulary is a collection of words that individuals know (Linse, 2006 P.121). Whereas (Hornby,1995 P.1331) stated that vocabulary is the number of words in a language. Every individual have definite collection words. An individual has total words different. In addition, an individual must know the vocabulary communicate with other individuals. According to ( Lehr , 2004 P.1) vocabulary is the knowledge of words and words that mean both oral and written. It can be said that vocabulary is an element in language.

\section{B. Blindfold}

Methods that teach students about things in class. After teaching vocabulary to students, both writing and pronunciation, to train descriptions of students we can use the blindfold game. Before entering games, it would be better if students were taught simple description phrases. Stepping into the game, students are usually asked to close their eyes with a sketch that has been prepared. After all students are blindfolded, the teacher will provide prepared things such as books, pencils, pens, etc. Students are asked to describe these objects. Students who succeed in describing and guessing objects correctly.

The blindfold game is one of the media that can improve students vocabulary. The blindfold game is a practical exercise in verbal communication that used to teach directions, numbers, and making instructions. Besides, this game can bring the students that they need to study the expressions of others to direct a person. The blindfold can impel team building activities more memorable and wearing blindfold can be fun. So that the students can be more interested and enjoy in English learning process.

\section{Methodology}

The method that will be use to analyze the data is classroom action research. Classroom action research is an activity and action to improve something that is planned, implemented, and evaluated in a systematic and systematic manner so that its validity and reliability reach the level of research. Action research is also a process that includes an action cycle, which is based on reflection, feedback, evidence, and evaluation of previous actions and current situations.

The number of participants in this study were 34 male and female students. Students involved in this research were eight grade students at school 31 Jakarta. This research was conducted on August 10, 2018 and the research will take 6 meetings. Instruments used are observation sheets, interview sheets, and documents including tests and blind folds.

Procedures that will be used in this study first the teacher asks permission from the principal to conduct research. After getting permission the teacher prepares all 
instruments, observation sheets, interview sheets, and blind fold test documents and then do research. Teachers will teach to teach them material related to daily activities. After this the teacher tells how to use blindfold in the class and asks them to participate in the blind fold method until they understand and master the vocabulary. After the teacher finishes asking how it feels to understand the vocabulary using blindfold.

The purpose of this study is to teach or correct vocabulary through the more interesting blindfold method in the English club.

Discussion

Process of The Research

\begin{tabular}{|c|c|c|}
\hline Cycle & Meeting & Activity \\
\hline $\begin{array}{l}1 . \\
\text { Enrich the vocabulary of } \\
\text { stationery and color in the } \\
\text { classroom. }\end{array}$ & $\begin{array}{l}\text { 1. Wednesday, } 5 \text { th of } \\
\text { September } 2018 \\
\text { 2. Thursday, 6th of September } \\
2018 \\
\text { 3. Friday, 7th of September } \\
2018\end{array}$ & $\begin{array}{l}\text { 1. Playing Blindfold with } \\
\text { stationery, color. } \\
\text { 2. Playing Blindfold with } \\
\text { think in the classroom. } \\
\text { 3. Post test }\end{array}$ \\
\hline $\begin{array}{l}2 . \\
\text { Encrich the vocabulary of } \\
\text { thinks in the bedroom, shape, } \\
\text { color, transportation, food, } \\
\text { fruit. }\end{array}$ & $\begin{array}{l}\text { 1. Wednesday, } 12 \text { th of } \\
\text { September } 2018 \\
\text { 2. Thursday, 13th September } \\
2018 \\
\text { 3. Friday, 14th September } 2018\end{array}$ & $\begin{array}{l}\text { 1. Playing Blindfold with } \\
\text { think in the bedroom, } \\
\text { shape. } \\
\text { 2. Playing Blindfold with } \\
\text { transportation, food. } \\
\text { 3. Post Test }\end{array}$ \\
\hline
\end{tabular}

In this study there were 3 meetings in each cycle. This cycle consists of four steps. They are plan, action, observation and reflection. The following is a brief description of the steps in cycle 1:

\section{Plan}

In this section, the researcher prepares vocabulary material using the blindfold method, the purpose of blindfold, the meaning of the vocabulary learned. The researcher also prepares tests and assessments. The movement for the first cycle is:

a. Playing Blindfold with stationery, color

b. Playing Blindfold with think in the classroom. 


\section{Action}

In this section, researchers apply actions based on lesson plans. This reaserch consists of three meetings in cycle one. Researchers teach students about the material using objects that are in the classroom.

The first meeting, the researcher explained about the material that had been prepared. To improve the clarity of students in understanding the material, researchers provide examples by using objects. Then at the end of time, researchers ask students who do not understand the material, and students ask researchers about material that is not understood. And researchers explained again about material that is not understood by students. and the researcher does not forget to conclude the material briefly but it is easy to understand

The second meeting, at the beginning of the time researchers asked about yesterday's material that was explained to remind again. Then, the researcher explained about the vocabulary in the form of objects in class. At the end of the meeting, students take a test.

\section{Observe}

In this section, researchers use observation checklists. The teacher explains the material about vocabulary, builds cases and ways to increase students' ability to understand vocabulary. The researcher explained the material aloud and the researcher presented the material briefly and clearly to make the students understand. And students pay attention, but there are still some students who don't pay attention. And make them not understand.

\section{Reflection}

First, the voice of researchers must be louder, researchers must pay attention to all students, and researchers are less in guiding and controlling students. Most students understand the material but there are some students who are not clear about the material, especially in their respective assignments. From reflection, the researcher explained the material briefly and clearly.

\section{Process of Cycle 1}

\begin{tabular}{|c|c|}
\hline Planning & $\begin{array}{l}\text { Topic : The Various Vocabulary } \\
\text { - Introduce various types of vocabulary and types. } \\
\text { - Playing Blindfold that uses cards to get to know various kinds of } \\
\text { vocabulary and types at each meeting. }\end{array}$ \\
\hline Action & $\begin{array}{l}\text { First meeting and Second meeting } \\
\text { - Give some examples of vocabulary and type. } \\
\text { - Explain how to play Blindfold for vocabulary. } \\
\text { - Monitor or pay attention to students who play Blindfold. } \\
\text { Third meeting } \\
\text { - Do the test }\end{array}$ \\
\hline Observation & $\begin{array}{l}\text { Student : } \\
\text { - Many students are curious about the Blindfold game. many of them are } \\
\text { also interested to immediately try the vocabulary game. Although there } \\
\text { are some students who are confused and wondering about the game. }\end{array}$ \\
\hline
\end{tabular}




\begin{tabular}{|l|l|}
\hline & The Teacher : \\
& - The teacher prepares the cobjects needed to be played. \\
- The teacher prepares a worksheet. \\
- The teacher monitors the course of the game. \\
Classroom situation : \\
- Classes become more lively and fun. \\
- Classes become more productive. \\
- Most students are active and very enthusiastic to participate.
\end{tabular}

The assessment aspects that will be given to students in this research are as below:

\section{Vocabulary Skills Rubric}

\begin{tabular}{|l|l|}
\hline $\begin{array}{l}\text { Excellent } \\
100-90\end{array}$ & $\begin{array}{l}\text { Complete knowledge of vocabulary. Excellent at identifying word meaning. No } \\
\text { spelling problems. }\end{array}$ \\
\hline $\begin{array}{l}\text { Very Good } \\
89-80\end{array}$ & $\begin{array}{l}\text { Good vocabulary knowledge. Good at identifying word meaning. No problems } \\
\text { with spelling. }\end{array}$ \\
\hline $\begin{array}{l}\text { Good } \\
79-70\end{array}$ & $\begin{array}{l}\text { General vocabulary knowledge. Able to identify word meaning. Some spelling } \\
\text { problems without interfering understanding. }\end{array}$ \\
\hline $\begin{array}{l}\text { Fair } \\
69-60\end{array}$ & $\begin{array}{l}\text { Still acceptable vocabulary knowledge. Still able to identify word meaning. } \\
\text { Some spelling problems without fully interfering understanding. }\end{array}$ \\
\hline $\begin{array}{l}\text { Fail } \\
59 \text { or fewer }\end{array}$ & $\begin{array}{l}\text { Lack of vocabulary knowledge. Misspelled words. Unable to identify word } \\
\text { meaning. }\end{array}$ \\
\hline
\end{tabular}

This is a table score of the first cycle.

\begin{tabular}{|c|c|c|c|c|c|c|c|}
\hline \multirow[b]{2}{*}{ No. } & \multirow[b]{2}{*}{ Name } & \multicolumn{5}{|c|}{ Aspects } & \multirow[b]{2}{*}{$\begin{array}{l}\text { Total } \\
\text { Score }\end{array}$} \\
\hline & & $\begin{array}{l}\text { Excellent } \\
(100-90)\end{array}$ & $\begin{array}{l}\text { Very Good } \\
(89-80)\end{array}$ & $\begin{array}{c}\text { Good } \\
(79-70)\end{array}$ & $\begin{array}{c}\text { Fair } \\
(69-60)\end{array}$ & $\begin{array}{c}\text { Fail } \\
(59 \text { or } \\
\text { fewer) }\end{array}$ & \\
\hline 1 & Reyhan & & & 70 & & & 70 \\
\hline 2 & Rizki & & & & & 59 & 59 \\
\hline 3 & Deja & & & & 65 & & 65 \\
\hline 4 & Shahnaz & & & & 60 & & 60 \\
\hline 5 & Desvia & & & 70 & & & 70 \\
\hline 6 & Restu & & & & 63 & & 63 \\
\hline 7 & Irfan & & & & & 57 & 57 \\
\hline 8 & Rafid & & & & 60 & & 60 \\
\hline 9 & Azki & & & & & 55 & 55 \\
\hline 10 & Fazriyah & & & & 60 & & 60 \\
\hline 11 & Nuri & & & & 65 & & 65 \\
\hline
\end{tabular}




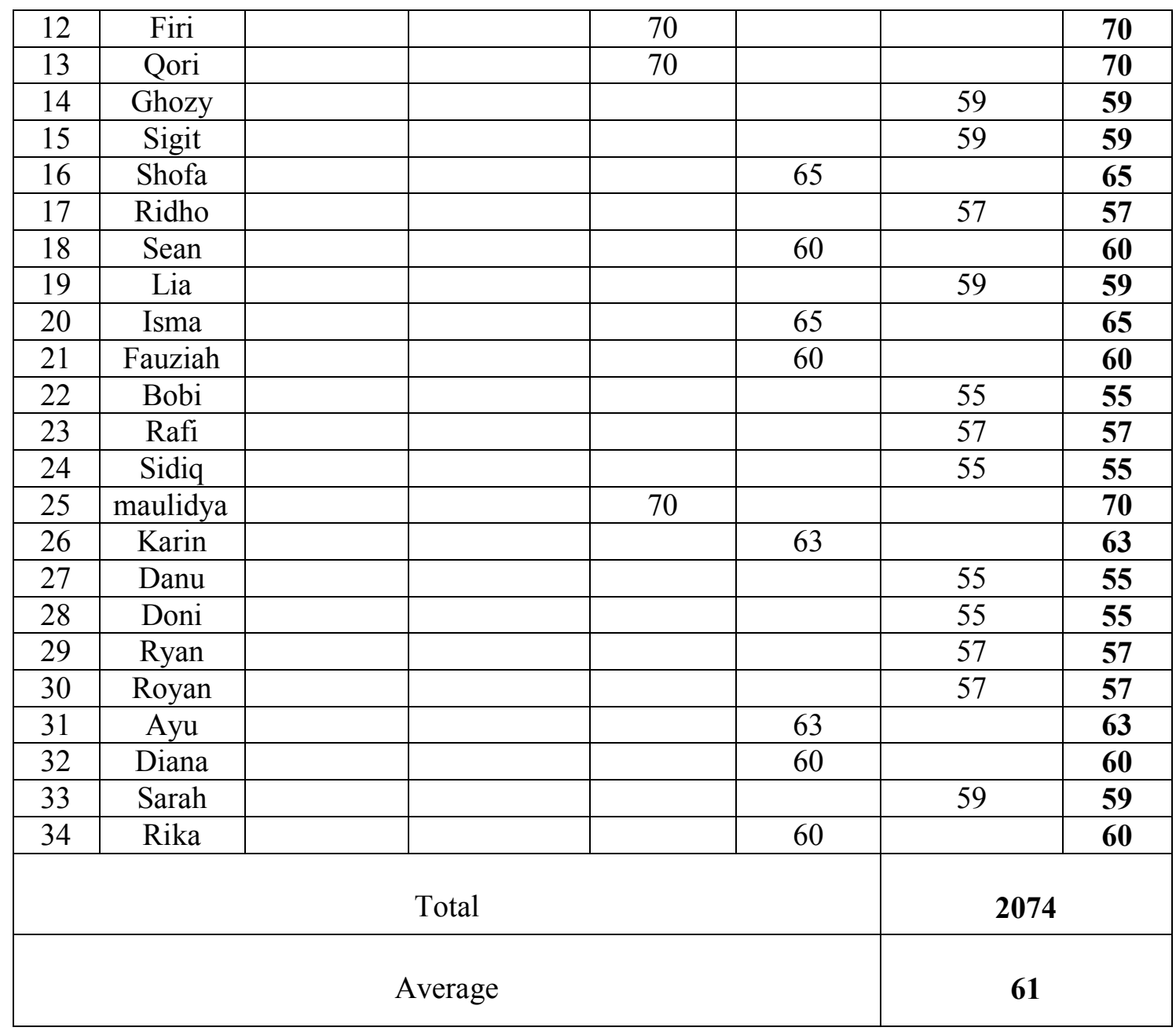

From the results above stated that almost all students get grades under the Minimum Completeness Criteria or KKM of the school. KKM schools in English are 65. There are 5 students who get the lowest score, 55. Then the other 5 students get 57 . Then the other 7 students get 60 . Then the other 3 students get 63 . Then 4 students get 65 . But the interesting thing is, in Cycle 1 there is 5 students who gets the value above the KKM school is 70 .

Because the value is insufficient, further research is needed, namely cycle two. In the second cycle also consists of four steps such as cycle one. The following is a brief description of the steps in cycle 2:

\section{Plan}

In this section, planning has been explained in cycle one. But in the second cycle, students focus more on the vocabulary given.

\section{Action}

Students start remembering and memorizing what vocabulary the researcher says and start the blindfold game. When the researcher starts assessing using an assessment rubric.

\section{Observation}


In this cycle, class is better than before. Students who memorize vocabulary develop significantly.

\section{Reflection}

From the previous cycle, based on the observation checklist analysis there were several performance improvements in the classroom. Researchers succeeded in improving students' ability to memorize vocabulary using the blindfold method.

\section{Process of Cicle 2}

\begin{tabular}{|c|c|}
\hline Planning & $\begin{array}{l}\text { Topic: The Various Vocabulary } \\
\text { - Introduce various types of vocabulary and types. } \\
\text { - Playing Blindfold that uses cards to get to know various kinds of } \\
\text { vocabulary and types at each meeting. }\end{array}$ \\
\hline Action & $\begin{array}{l}\text { First meeting and Second meeting } \\
\text { - Give some examples of vocabulary and type. } \\
\text { - Explain how to play Blindfold for vocabulary. } \\
\text { - Monitor or pay attention to students who play Blindfold. } \\
\text { Third meeting } \\
\text { - Do the test descriptive text about } \\
\text { 1. objects in the bedroom } \\
\text { 2. transportation, and favorite food. }\end{array}$ \\
\hline Observation & $\begin{array}{l}\text { Student : } \\
\text { - Many students are curious about the Blindfold game. many of them are } \\
\text { also interested to immediately try the vocabulary game. Although there } \\
\text { are some students who are confused and wondering about the game. } \\
\text { The Teacher: } \\
\text { - The teacher prepares the cobjects needed to be played. } \\
\text { - The teacher prepares a worksheet. } \\
\text { - The teacher monitors the course of the game. } \\
\text { Classroom situation : } \\
\text { - Classes become more lively and fun. } \\
\text { - Classes become more productive. } \\
\text { - Most students are active and very enthusiastic to participate. }\end{array}$ \\
\hline Reflection & $\begin{array}{l}\text { Strength : } \\
\text { - By playing Blindfold for vocabulary, students can increase their } \\
\text { vocabulary to add to their vocabulary. } \\
\text { - There is an increase or increase in vocabulary obtained by students. } \\
\text { - Students have begun to understand how to play the game. } \\
\text { - Students already understand how to play and memorize through } \\
\text { blindfold games. } \\
\text { Weaknesses : } \\
\text { - Students are still confused }\end{array}$ \\
\hline
\end{tabular}

This is a table score of the second cycle. 


\begin{tabular}{|c|c|c|c|c|c|c|c|}
\hline No. & Name & $\begin{array}{l}\text { Excellent } \\
(100-90)\end{array}$ & $\begin{array}{c}\text { Very Good } \\
(89-80)\end{array}$ & $\begin{array}{c}\text { Good } \\
(79-70)\end{array}$ & $\begin{array}{c}\text { Fair } \\
(69-60)\end{array}$ & $\begin{array}{c}\text { Fail } \\
\text { (59 or } \\
\text { fewer) }\end{array}$ & $\begin{array}{l}\text { Total } \\
\text { Score }\end{array}$ \\
\hline 1 & Reyhan & & & 78 & & & 78 \\
\hline 2 & Rizki & & & 70 & & & 70 \\
\hline 3 & Deja & & & 75 & & & 75 \\
\hline 4 & Shahnaz & & & 70 & & & 70 \\
\hline 5 & Desvia & & & 70 & & & 70 \\
\hline 6 & Restu & & & 70 & & & 70 \\
\hline 7 & Irfan & & & & 65 & & 65 \\
\hline 8 & Rafid & & & 75 & & & 75 \\
\hline 9 & Azki & & & 70 & & & 70 \\
\hline 10 & Fazriyah & & & 70 & & & 70 \\
\hline 11 & Nuri & & & 75 & & & 75 \\
\hline 12 & Firi & & & 75 & & & 75 \\
\hline 13 & Qori & & & 78 & & & 78 \\
\hline 14 & Ghozy & & & & 69 & & 69 \\
\hline 15 & Sigit & & & & 65 & & 65 \\
\hline 16 & Shofa & & & 70 & & & 70 \\
\hline 17 & Ridho & & & & 69 & & 69 \\
\hline 18 & Sean & & & & 65 & & 65 \\
\hline 19 & Lia & & & & 65 & & 65 \\
\hline 20 & Isma & & & 70 & & & 70 \\
\hline 21 & Fauziah & & & & 65 & & 65 \\
\hline 22 & Bobi & & & & 65 & & 65 \\
\hline 23 & Rafi & & & & 69 & & 69 \\
\hline 24 & Sidiq & & & & 69 & & 69 \\
\hline 25 & maulidya & & & 78 & & & 78 \\
\hline 26 & Karin & & & 75 & & & 75 \\
\hline 27 & Danu & & & & 65 & & 65 \\
\hline 28 & Doni & & & & 65 & & 65 \\
\hline 29 & Ryan & & & & 65 & & 65 \\
\hline 30 & Royan & & & & 65 & & 65 \\
\hline 31 & Ayu & & & 70 & & & 70 \\
\hline 32 & Diana & & & 70 & & & 70 \\
\hline 33 & Sarah & & & & 69 & & 69 \\
\hline 34 & Rika & & & & 69 & & 69 \\
\hline \multicolumn{6}{|c|}{ Total } & \multicolumn{2}{|c|}{2373} \\
\hline \multicolumn{6}{|c|}{ Average } & \multicolumn{2}{|c|}{70} \\
\hline
\end{tabular}

from the results of the cycle above cycle one and cycle two it can be seen that the second cycle experienced a very significant change. can be seen from the diagram below. 


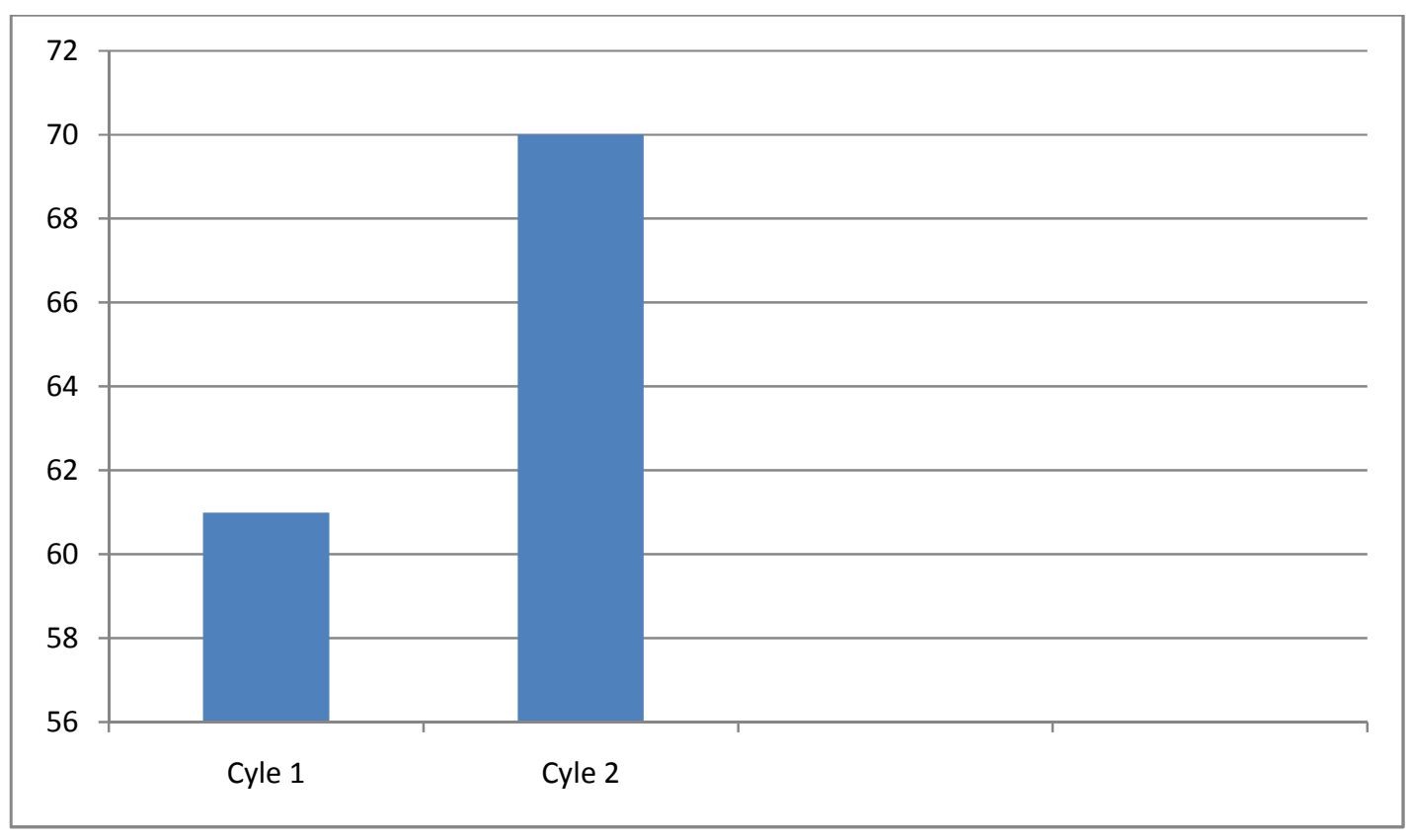

In the first cycle when taking vocabulary values using blindfold games, the average result of 34 students is 61 . This is a good start for beginners. Initially during the first meeting, students were still confused about playing blindfold. But, after trying to apply blindfold games, students better understand vocabulary.

In the second cycle, obtained a large average of 70. in this cycle, students' understanding of vocabulary was better, and they already understood the use of vocabulary. Students play blindfod with great enthusiasm, and their understanding increases. To get the score above the researcher uses a scoring rubric. In addition, we also provide categories of assessment rubrics that are shown in the table above. Based on the results above, it can be seen that the students 'test scores, the average cycle of one is 61 and the second cycle is 70 . This shows that there is an increase in students' ability to understand vocabulary between cycle one and cycle two.

\section{Conclusion}

The conclusion is that vocabulary taught in the old way can make students bored so that this method makes a method of understanding vocabulary not saturated and boring because this method is blindfold, with this blindfold students will better understand vocabulary because this blindfold is made in a fun way 34 students argue that this blindfold make them understand their vocabulary and meaning.

\section{REFERENCES}

andriyani, r. (2017). the implementation of blindfold game media to improve students vocabulary mastery at mtsn nurul huda tanjung pura.

Hornby. 1995. Advance Learner's Dictionary. New York: Oxford University Press.

Linse, Caroline T. 2006. Practical English Language Teaching : Young Learners. New York: McGraw Hill. 
Marzuki, H. (2015). IMPROVING STUDENTS VOCABULARY MASTERY BY USING PICTURES MEDIA AT THE THIRD GRADE OF SDN 010 KEPENUHA.

muttahidah, n. (2011). improving studdents vocabulary trough vocabulary card.

Nunan, 2005. Language Teaching Methodology. A Textbook for Teachers. London: Prentice Hall

rasyidaj, m. t. (2017). TEACHING VOCABULARY FOR THE SECOND GRADE

STUDENTS OF SMP A-ISLAM KARTASURA IN ACADEMIC YEAR 2017/2018 .

Richards, J and Renandya W. 2002.Methodology in Language Teaching:An Anthology of Current Practice. Cambridge: Cambridge University Press

wardani, s. i. (2015). IMPROVING STUDENTS' VOCABULARY MASTERY.

yuliani, r. (2010). interaksi sosial dalam kelompok english public speaking club di smp-sma semesta bilingual boarding school gunung pati semarang.

http://www.belajarbahasainggris.us/2012/12/permainan-kosa-kata-vocabulary-

games.html?m=1 